\title{
Examining the Instructional Contexts of Students with Learning Disabilities
}

\author{
JANIS A. BULGREN \\ University of Kansas Institute for Research in Learning Disabilities \\ JUDITH J. CARTA \\ University of Kansas Juniper Gardens Children's Project
}

\begin{abstract}
This review of the literature examines how instructional contexts for elementary and secondary level students with learning disabilities have been studied in the past 10 years through a variety of methodological approaches and observation instruments. These studies employed some direct measure of classroom ecology, as well as some measure of the teacher or students' classroom behavior. Information included the time that students were engaged in different activities in different settings, interactions between teachers and students, and students' classroom behavior.
\end{abstract}

Several factors contribute to the need to study the instructional contexts of students with learning disabilities. Among these factors are the variety of classroom environments in which these students receive instruction, the need for teaching practices that allow these students to learn more effectively and efficiently, and student characteristics that create challenges for both the student and the teacher if student potential is to be realized.

A primary reason for examining the educational contexts for students with learning disabilities is the variety of classroom environments in which these students receive instruction. Recent educational movements make it probable that many of these students will have to adjust to a variety of different settings each day. This movement has partly resulted from the least restrictive environment philosophy expressed in Public Law 94-142 and from the recent regular education initiative, which seeks the placement of students with disabilities in the regular classroom for at least part of their instruction (National Joint Committee on Learning Disabilities, 1983; Pugach \& Lilly, 1984; Reynolds, Wang, \& Walberg, 1987; Stainback \& Stainback, 1984;
Will, 1986). The variety of instructional contexts encountered each day by students with learning disabilities is, in itself, challenging. This challenge is complicated by other factors, such as the need for effective teaching practices for all students, but especially for those with learning disabilities.

Therefore, a second area of interest is that of teacher behavior that is directed toward students with learning disabilities. A teacher's behavior, as part of the instructional context, has the potential of affecting students' academic time on task, critical to student performance. Indeed, research has demonstrated that with effective teaching practices, students with learning disabilities can exhibit academic behavior that looks much like that of their peers without disabilities (Idol, 1987; Short \& Ryan, 1984; Sindelar, Monda, \& O'Shea, 1990). Effective teaching practices have positively affected the learning of students with learning disabilities by increasing the amount of time during which students are actively engaged in academic responding.

Another consideration in the complex analysis of instructional contexts is the actual behavior shown by students with learning disabilities. 
These students need to increase the time devoted to active learning and the number of interactions with teachers. Students with learning disabilities have been characterized as "inactive learners" (Torgeson, 1977, 1982) or "disassociated learners" (Kavale \& Forness, 1986) who do not participate actively in the learning process. Recalling the work of Carroll (1963), Kavale and Forness pointed out that when academic learning time (i.e., the proportion of engaged time in which the student is experiencing a high degree of success) is inadequate, a student can disassociate from school learning.

Therefore, enhancing students' opportunities to respond actively in the educational process could result in increased and cumulative gains for students with learning disabilities. Analysis of instructional contexts, including different settings and teacher and student behavior, contributes to the identification of specific areas of educational need.

This article reviews studies over the past 10 years of instructional contexts for students with learning disabilities-methodologies, instruments, and findings. The review highlights major research questions about instructional contexts, delineates the current questions, and discusses the most important questions that still remain. The overriding purpose of this article is to show how research has examined the educational contexts of students with learning disabilities and has laid the foundations for more effective and efficient instructional practices for this group of students.

\section{METHODOLOGY FOR THIS REVIEW}

We chose research-based articles that focused on some aspect of the instructional context of students with learning disabilities at the elementary or high school level. Studies we included used some direct measure of the classroom ecology, as well as a measure of the teacher or students' classroom behavior. Ecological measures included variables such as tasks, activities, or the level of structure employed in the classroom.

We undertook the following literature search procedures: First, we reviewed journals related to special education and learning disabilities (e.g., Exceptional Children, Journal of Learning Disabilities, Journal of Special Education, Learning Disability Quarterly, and Remedial and SpecialEducation). Second, we conducted an ancestral search that traced relevant studies that were referenced in articles obtained in the journals reviewed in Step 1. Finally, we undertook a computer search of theEducational Resources Information Center (ERIC) database from 1981 to the present. We located a total of 16 studies meeting the stated criteria.

\section{CLASSROOM ENVIRONMENTS FOR STUDENTS WITH LEARNING DISABILITIES}

The student with learning disabilities is commonly placed in some combination of settings that may include a regular classroom, a self-contained classroom, a consulting-teacher classroom, or a resource room setting for a variable part of the school day (Carlberg \& Kavale, 1980; Greenwood, 1985; Madden \& Slavin, 1983). As a means of responding to this complexity of settings, researchers have asked ecological questions that arise from the placement of students in these various instructional environments. One important set of ecological questions regards how students in various types of settings spend their time engaged in different activities and instructional structures. These variables have been defined as "ecological events" (Greenwood, Delquadri, Stanley, Terry, \& Hall, 1985). Studies suggest that, although class structure in special education classrooms often differs from that in regular education classrooms, teachers in both settings often allocate similar amounts of time to various instructional activities.

One focus of researchers from the University of Minnesota's Institute for Research on Learning Disabilities was a comparison of students with learning disabilities across different settings, such as the regular classroom and the special education classroom. One study by Ysseldyke, Thurlow, Mecklenburg, Graden, and Algozzine (1984) was designed to discover whether students with learning disabilities received more time devoted to instruction after referral out of the regular class and placement in a special classroom. These researchers used the Code for Instructional Structure and Student Academic Response (CISSAR) (Stanley \& Greenwood, 1981), a momentary time-sampling observation system that allows the recording of students' opportunities to engage in active academic responses as a function of different features in their instructional environments. Ysseldyke and his colleagues found that for three out of four students in their study, time allocated 
to instruction and time engaged in academic responding were only marginally affected by placement in the special program. Academic instructional time increased shortly after placement in the special education program, but the average gain was reduced almost to the level before placement when students were observed 2 months after placement.

In a similar study, Thurlow, Ysseldyke, Graden, and Algozzine (1984) asked whether students with learning disabilities were exposed to different instructional ecologies in service levels that ranged in their amount of restrictiveness. Using the CISSAR system, they observed students in service levels ranging from full-time placement in the regular classroom to full-time placement in the special education classroom. The authors reported finding minimal ecological differences across the five service levels and no differences across service levels in students' opportunities to learn through active academic responding. For example, though more time was allocated in less restrictive settings to academic activities such as reading and math, no differences were found in these settings in time allocated to nonacademic activities, arts and crafts, transition, free time, and management activities. In addition, no differences were found in less restrictive settings in the amounts of time allocated to any specific task, such as working with readers or notebooks. Students in these settings were allocated more time for whole-group teaching structures than were students within more restrictive settings. Students within more restrictive settings were allocated more time for individual teaching structures. No differences were found across these five settings in time allocated to small-group structures.

More recent studies by the Minnesota group have examined classroom ecological differences for students with learning disabilities, as compared with students with other types of disabilities (such as those with mental retardation or emotional disturbance) or as compared with students without disabilities. In one such study using the CISSAR code, Ysseldyke, Thurlow, Christenson, and Weiss (1987) compared the amount of time allocated to instruction in specific subject-matter areas for students with and without disabilities in elementary school classrooms. The authors also examined the amount of time that students with various disabilities spent in special education and regular classes and also examined the differences in the proportion of time allocated to specific subject-matter instruction in special education or regular settings. They failed to find many differences in the amount of time allocated to instruction in various activities for students in different categories at the elementary level. Students with learning disabilities spent less than $3 \mathrm{hr}$ a day in regular education settings and less than $1 \mathrm{hr}$ per day in special education settings. (In addition, the authors determined that a greater proportion of time was allocated to academic activities in special education than in regular classes.)

In a similar study, Ysseldyke, Christenson, Thurlow, and Bakewell (1987) compared the instructional tasks presented to students with learning disabilities, students with two other types of disabilities, and students without disabilities. Again, just as they found minimal differences in the allocation of time in different subject areas, here they found minimal differences in instructional tasks, that is, the curriculum materials or the stimuli provided by the teacher as a function of disability category or as a function of instructional setting.

Finally, other researchers have used ecobehavioral analysis to study the effectiveness of various interventions in enhancing the performance of students with learning disabilities. Greenwood, Carta, Arreaga-Mayer, and Rager (1991) used the Mainstream version of the CISSAR code (MS-CISSAR) to identify a set of potentially effective procedures in naturalistic classroom instruction. They used students' gains in academic achievement and observed academic behavior to identify effective versus ineffective instructional procedures in language arts classes containing students with learning disabilities.

The authors found that direct instruction was effective both in a resource room setting and a regular education classroom. They pointed out the utility of a search-and-validate approach to development and evaluation of effective instruction. They contended that it is an approach consistent with current school improvement goals because it focuses on student achievement, analysis of classroom behavior, and features of classroom instruction.

In summary, research on the classroom environments of students with learning disabilities has revealed some differences in classroom structure across regular and special education settings, but few differences in time devoted to various subjects or tasks in these settings. These findings raise critical questions regarding how 
each setting should be configured to respond to the needs of students with learning disabilities. An important use of instructional analysis has also been to link information gained from analysis of these instructional contexts to achievement gains.

\section{TEACHING BEHAVIOR DIRECTED AT STUDENTS WITH LEARNING DISABILITIES}

Another important aspect of the instructional context is the types of teaching behavior that are directed toward students with learning disabilities. Several studies have explored the quantity as well as the quality of teachers' interactions with these students. Examinations were conducted for students with learning disabilities in the regular classroom, for such students who move from the regular to special classrooms, and for students who remain in special classrooms. These analyses have provided information regarding differences in the type and quality of interactions of regular classroom teachers toward students with and without learning disabilities. Further comparisons have been made between treatments received by students with learning disabilities and students with other disabilities in special education classrooms. Details of these studies are provided as follows.

\section{Observations in Regular Classes}

Several researchers have studied students with learning disabilities in the environment of the regular classroom. One set of studies found differences in quality but not the quantity of types of teacher behavior toward these students in the regular classroom. For example, Slate and Saudargas (1986) examined whether regular teachers' behavior was different when directed at boys without learning disabilities. These researchers employed the State-Event Classroom Observation System (SECOS) (Saudargas \& Creed, 1980), a system that uses a 15-s momentary time-sampling procedure to capture the state of student behavior (e.g., schoolwork) and specific events, such as hand raising or calling out. Slate and Saudargas found that although the regular teachers engaged in contacts with all boys for an equivalent amount of time, the teachers provided the boys with disabilities with a disproportionate amount of attention when these boys were engaged in an activity other than the pre- scribed academic assignment. This was true even though the boys with disabilities may have engaged in similar amounts of inappropriately engaged behavior as had the boys without disabilities.

Similarly, Fellers and Saudargas (1987), also using the SECOS code, attempted to determine any major differences in teacher behavior toward elementary school girls with learning disabilities and those without disabilities in the regular classroom. They found that teachers did not spend more time interacting with girls with disabilities, but they ignored call-outs from girls with disabilities more than from girls without disabilities. This finding is apparently inconsistent with the previous finding (Slate \& Saudargas, 1986) concerning boys with learning disabilities. According to Fellers and Saudargas, teachers may perceive boys with learning disabilities as having more behavioral problems than girls with the same disabilities. Consequently, teachers may find it necessary to monitor the behavior of these boys more closely than the behavior of girls with learning disabilities.

In another variation of this study, Slate and Saudargas (1987) examined how teachers responded to the specific behavior of students with different types of disabilities and of students without disabilities using the SECOS and a lag sequential analysis. Lag sequential analysis is a nonparametric statistic that permits quantitative descriptions of temporal relationships among individual behaviors that occur in sequences (Sackett, 1978). They found that the teachers seemed to respond differently to students with disabilities depending on the behavior in which the students were engaged. On one hand, the teacher was more likely to leave the students with learning disabilities alone when they were working on schoolwork, than when they were engaged in other types of behavior. On the other hand, the teacher was more likely to interact with them when the students with learning disabilities were out of seat or interacting with other children, than when they were not engaging in those types of behavior. When interactions between teachers and students with learning disabilities occurred, they lasted longer than interactions with students without disabilities. This differential attention to the off-task behavior of students with learning disabilities was not found toward students without disabilities.

Another set of studies using a different observation system found differences in both the quan- 
tity and the quality of teacher behavior toward students with and without learning disabilities in the regular classroom. Studies by Alves and Gottlieb (1986) and Siperstein and Goding (1985), using the Brophy-Good Teacher-Child Dyadic Interaction System (Brophy \& Good 1972) to record the interactions between a child and his or her teacher, often reported greater frequencies of interaction between teachers and students with learning disabilities than between teachers and students without disabilities. The Brophy-Good Teacher-Child Dyadic Interaction System is an interval-based, time-sampling system that records five categories of teacher-student interactions. Using this system, Siperstein and Goding found that teachers initiated more interactions, responded with greater frequency of corrective behavior, and used more nonsupportive verbal and negative nonverbal behavior with students with learning disabilities than with other children. An intervention designed to make elementary school teachers aware of their behavior did not affect the quantity of interactions between teachers and students with learning disabilities, but it significantly reduced the negative quality of these interactions.

Alves and Gottlieb (1986) also found differences in the quantity of time teachers spent with students with disabilities, but they provided additional information regarding differences in the quality of academic time for different groups. Using an adaptation of the Brophy-Good system, Alves and Gottlieb found that teachers' academic questions and extended feedback to students were the main variables that discriminated between two groups of students: students with mild disabilities and those without disabilities. Although the students with disabilities interacted with teachers more frequently than with the students without disabilities, teachers directed fewer academic questions and provided less extended feedback to students with disabilities than to their peers without disabilities. As a result, students with disabilities had fewer opportunities for active academic involvement. Alves and Gottlieb raised serious concerns that regular teachers may not have provided as much academic input to their students with disabilities because they considered socialization and not academic learning to be the primary goal of mainstreaming for these students. Alves and Gottlieb hypothesized that if the teachers believed their primary role was to promote these students' socialization and emotional adjustment, then they may have placed these goals above that of teaching content. In addition, if these teachers attributed those students' achievement problems to inherent limitations in ability, they may have treated these pupils in ways that ultimately hampered their achievement.

\section{Observations Across Classrooms}

Other researchers have examined the types of behavior that teachers direct toward students with learning disabilities throughout the day in both the regular classroom and the resource room. These researchers have found differences in the quantity as well as the quality of time that teachers spend with students with learning disabilities. For example, in the study described earlier using the CISSAR code, Thurlow and her colleagues (Thurlow, Graden, Greener, \& Ysseldyke, 1983) found that students with learning disabilities received significantly more teacher approval than did the students without disabilities. In addition, the students with disabilities received more individual instruction with the teacher at their side than did the other students. Because this study observed students with learning disabilities in both the regular classroom and the resource room, further analysis may be warranted to determine how teacher behavior differs in each setting.

\section{Observations in Special Classes}

Other studies have compared the teaching behavior directed toward students with learning disabilities, with that directed to other special populations. In a study using the Classroom Observations Keyed for Effective Research (COKER) (Coker, \& Coker, 1982), Algozzine, Morsink, and Algozzine (1988) compared the nature of instruction provided in self-contained special education classrooms for students with different types of disabilities. The authors found few differences in the instructional behavior of special education teachers relative to the type of student in their self-contained classrooms. In general, instructional activities and communication patterns were similar for classes containing students with learning disabilities, emotional disturbance, or mild mental retardation.

In another study using the CISSAR code, O'Sullivan, Marston, and Magnusson (1987) explored the differences in behavior of special educators who held differing teacher licensure in the areas of learning disabilities and mild mental re- 
tardation. They found no differences in the instructional behavior of teachers in these areas of special education. Furthermore, they found that the classroom behavior of groups of students with learning disabilities and mild mental retardation did not differ. Finally, pupil behavior did not differ as a function of teacher licensure. Therefore, placement in different categorical classrooms appears to have provided little difference in the instruction received by students in various special education classes.

In summary, research presents somewhat mixed results regarding the quantity of time that regular classroom teachers spend with students with learning disabilities as compared with other students. Researchers have, however, found several differences in the quality of interactions between regular classroom teachers and students with and without learning disabilities and have begun to compile a composite picture of the types of teacher behavior often directed toward these students. This picture often reveals less interaction with these students on academic matters, and more frequent, longer, and corrective interactions on nonacademic matters, especially for boys with learning disabilities in the regular classroom. The quality of teacher behavior may vary from setting to setting. Within special education classrooms, however, students with learning disabilities do not appear to be treated differently from students with other disabilities.

A major question is, of course, whether the different quality of interactions experienced by students with learning disabilities and their teachers has an effect on those students' academic responding and achievement. It would appear that this could be the case; if so, research could well pinpoint problem areas, identify successful adjustments, and suggest optimal learning conditions in teacher interactions with students with learning disabilities.

\section{CLASSROOM BEHAVIOR OF STUDENTS WITH LEARNING DISABILITIES}

The analysis of the behavior of students with learning disabilities within their instructional contexts has been instructive in describing those students' learning characteristics within specific educational settings. In the literature reviewed, student responses were typically categorized as academic responses, task-management responses, or competing-behavior responses
(Greenwood et al., 1985). These were most often considered with the student as the focal point because within the context of the classroom, a given student may or may not be responding in a manner envisioned by the teacher. The studies described below focus on the following areas of student behavior: inappropriate behavior of students with learning disabilities in the regular classroom, differing academic behavior of students with and without learning disabilities, and differing academic behavior of students with learning disabilities in different educational settings.

\section{Inappropriate Student Behavior}

First, some researchers have focused on differences between students with and without learning disabilities in the regular classroom. Ecological studies have produced results suggesting that students with learning disabilities may behave differently from other students, especially in their relative levels of inappropriate responses. McKinney and Feagans (1984) observed elementary school students with learning disabilities in the regular classroom during academic activities. These researchers used the Schedule for Classroom Activity Norms (SCAN), a time-sampling system that records task-oriented, social, and affective behavior as well as the settings in which the behavior occurs. The researchers found that the students with learning disabilities tended to be less on-task and to exhibit more off-task behavior than their classmates without disabilities. They were also more distractible and dependent/aggressive. McKinney and Feagans noted that this was particularly significant in that offtask behavior is negatively correlated with academic progress.

Fellers and Saudargas (1987) attempted to determine differences in the levels of academic behavior of a group of female elementary school students with disabilities and a similar group of female students without disabilities. Again, the SECOS observation system described earlier was used. The most significant difference between the two groups of students was that the girls with learning disabilities spent less time engaged in schoolwork than did girls without disabilities. In yet another study, comparing the classroom behavior of elementary school students with and without learning disabilities, Slate and Saudargas (1987) found that after interacting with the teacher, children with disabilities took longer to 
return to their school work than did their peers without disabilities. As a result, at the elementary school level, students with learning disabilities appeared to behave differently than students without disabilities in regular classrooms, by exhibiting more types of inappropriate behavior.

Studies have also been conducted regarding the behavior of adolescents in mainstream secondary-level classes. Bender (1985) found that the students with learning disabilities demonstrated more passive off-task behavior than did their low-achieving peers, although during whole-group instruction, both groups were more likely to be off-task in a passive manner than they were during seatwork. A study by Zigmond, Kerr, and Schaeffer (1988) supported the description of the adolescent with learning disabilities in the secondary mainstream classrooms as a passive learner who does not come to class with appropriate materials, who attends to instruction only about $60 \%$ of the time, who generally does not give information or ask questions, but who generally follows the teacher's procedural directions. Using a special observation system (Harris, Brown, Kerr, \& Zigmond, 1983), their study found that such performance was not significantly different from that of students in a contrast group of adolescents without disabilities. The authors pointed out the need to collect information on students without disabilities to provide a perspective on normal adolescent behavior, particularly if the behavior of students with learning disabilities becomes more like that of other students as they progress from the elementary to the secondary level.

\section{Academic Behavior of Students with and Without Learning Disabilities}

In addition to studies that focus on appropriate versus inappropriate behavior in the regular classroom, other studies have produced results regarding specific student academic responses. Researchers using the CISSAR code have examined the nature of instruction and academic responding time for students with and without learning disabilities. Thurlow et al. (1983) explored the active academic responses (in addition to the time allocated to various activities and tasks discussed earlier) of students with and without learning disabilities and found that the two groups did not differ in total active academic responding times overall, in task management responses overall, or in inappropriate responses overall. The two groups of students differed in the time they spent engaged in specific types of academic responses. For example, students without learning disabilities spent more time writing than did students with disabilities, whereas the latter students spent more time playing academic games, reading aloud, talking about academics, answering academic questions, and asking academic questions. However, these authors found that, in general, the total academic responding time for both groups of students with and without learning disabilities was extremely small and variable.

\section{Academic Behavior of Students with Learning Disabilities Across Settings}

In another investigation, the academic responding level of students with learning disabilities was observed and contrasted in different educational settings. Thurlow et al. (1984), again using the CISSAR code, observed five different instructional levels for students with learning disabilities, ranging from full-time placement in the regular classroom to full-time placement in resource rooms, and found no significant differences across the five levels in the time students with learning disabilities spent in various responses. In addition, no significant differences across the levels were found in the proportion of time that the students with disabilities were engaged in academic responses overall, task management responses overall, or inappropriate responses overall. Students were engaged in task management for the greatest amount of time; followed by academic responses, for less than half the time spent in task management; and then by inappropriate responses, for approximately a third of the time spent in task management. Variability among students was great, even within the same type of placement. On the whole, academic responding time was low for all students, averaging less than 45 min per day.

In summary, research that focuses on students with learning disabilities in the mainstream classroom yields a picture of students who, according to some researchers (specifically those using the SCAN, the SECOS, and Bender's technique), may differ in behavior from students without disabilities in that they may be less on-task. Studies across a variety of educational settings (particularly studies using the CISSAR code) suggest that students with learning disabilities often appeared to respond somewhat differently than did other 
students, in terms of time spent in specific types of academic response even though total academic responding time was not different. However, students with learning disabilities do not appear to behave differently in different educational settings.

\section{CONCLUSION}

This review of the literature, focusing on the instructional contexts of students with learning disabilities, has answered some descriptive questions regarding this population but has also raised other questions. At issue is the apparent lack of significant differences found by some researchers in instruction for students with learning disabilities in special and regular education settings. We suggest future research in the following areas: quality and quantity of student and teacher interactions, effects of teacher training programs, behavior of students with learning disabilities across occasions and settings, and effective interventions for these students.

Specifically, questions about teachers in special education classrooms include the following: Does different teacher licensure lead to different teacher behavior in classrooms? Do teachers in special education classrooms treat all special education students similarly, regardless of special education classification? If so, what are the educational implications? Further questions regarding student behavior include the following: Do students with learning disabilities behave more like students with disabilities or like students without disabilities? How do instructional settings affect their behavior? Do students with learning disabilities behave more like students without disabilities as they progress from the elementary to secondary level?

Studies examining instructional contexts of students with learning disabilities have advanced our knowledge base by providing specificity regarding these students' interactions with subject matter, curriculum, tasks, and group structure or arrangements across various settings. The results of such studies lay the foundations for further exploration regarding the ecological settings in which students with learning disabilities can best be provided with effective instructional procedures. In addition, such data may suggest ways to structure instruction to best meet the needs of various individuals through ongoing manipulation and exploration of educational techniques. As Carta and Greenwood (1985) pointed out, the data produced in ecological assessment are immediately sensitive to the effects of relatively small adjustments made in instructional methods and materials. Therefore, these analyses can guide the manipulations of classroom variables to determine the precise configurations within a setting that will enhance academic gains for students with learning disabilities.

Of course, the ultimate question is the identification of the academic procedures and classroom structures that will increase the academic gains of students with learning disabilities. Given the characteristics of students with learning disabilities, the variety of settings in which they are placed, the numerous setting demands to which they must respond, and the importance of time engaged in the learning process, careful research into quality teaching procedures is critical to this group of students.

\section{REFERENCES}

Algozzine, B., Morsink, C. V., \& Algozzine, K. M. (1988). What's happening in self-contained special education classrooms? Exceptional Children, 55, 259-265.

Alves, A. J., \& Gottlieb, J. (1986). Teacher interactions with mainstreamed handicapped students and their nonhandicapped peers. Learning Disability Quarterly, 8, 77-83.

Bender, W. N. (1985). Differential diagnoses based on the task-related behavior of learning disabled and low-achieving adolescents. Learning Disability Quarterly, 8, 261-266.

Brophy, J., \& Good, T. (1972). Brophy-Good System (Teacher-Child Dyadic interaction). In A. Simon \& E. Boyer (Eds.), Mirrors for behavior: An anthology of observation instruments continued (Vol. A, pp 191-197). Philadelphia: Research for Better Schools.

Carlberg, C., \& Kavale, K. (1980). The efficacy of special versus regular class placement for exceptional children: A meta-analysis. Joumal of Special Education, 14, 295-306.

Carroll, J. B. (1963). A model of school learning. Teachers' College Record, 64, 723-733.

Carta, J. J., \& Greenwood, C. R. (1985). Ecobehavioral assessment: A methodology for expanding the evaluation of early intervention programs. Topics in Early Childhood Special Education, 5, 88-104.

Coker, J. G., \& Coker, H. (1982). Classroom observations keyed for effective research: User's manual. Carrolton, GA: Author.

Fellers, G., \& Saudargas, R. A. (1987). Classroom behaviors of LD and nonhandicapped girls. Learning Disability Quarterly, 10, 231-236.

Greenwood, C. R. (1985). Settings or setting events as treatment in special education: A review of 
mainstreaming. In M. L. Wolraich (Ed.), Advances in developmental and behavioral pediatrics (Vol. 6 , pp. 205-239). Greenwich, CT: JAI Press.

Greenwood, C. R., Carta, J. J., Arreaga-Mayer, C., \& Rager, A. (1991) The behavior analysis consulting model: Identifying and validating naturally effective instructional models. Journal of Behavioral Education, 1, 165-191.

Greenwood, C.R., Delquadri, J., Stanley, S. O., Terry, B., \& Hall, R. V. (1985). Assessment of ecobehavioral interaction in school settings. Behavioral Assessment, 7, 331-347.

Harris, A., Brown, G., Kerr, M. M., \& Zigmond, N. (1983). Training manual for research assistants (Tech. Rep. No. 6). Pittsburgh: University of Pittsburgh.

Idol, L. (1987). Group story mapping: A comprehension strategy for both skilled and unskilled readers. Journal of Learning Disabilities, 20, 196-205.

Kavale, K. A., \& Forness, S. R. (1986). School learning, time and learning disabilities: The disassociated learner. Journal of Learning Disabilities, 19, 130138.

Madden, N. A., \& Slavin, R. E. (1983). Mainstreaming students with mild handicaps: Academic and social outcomes. Review of Educational Research, 53, 519 569.

McKinney, J. D., \& Feagans, L. (1984). Academic and behavioral characteristics of learning disabled children and average achievers: Longitudinal studies. Learning Disability Quarterly, 7, 251-265.

National Joint Committee on Learning Disabilities. (1983). Learning disabilities: Issues on definition (position paper). Learning Disability Quarterly, 6, 42-44.

O’Sullivan, P. J., Marston, D., \& Magnusson, D. (1987). Categorical special education teacher certification: Does it affect instruction of mildly handicapped pupils? Remedial and Special Education, 8(5), 13-18.

Pugach, M., \& Lilly, M. S. (1984). Reconceptualizing support services for classroom teachers: Implications for teacher education. Journal of Teacher Education, 35(5), 48-55.

Reynolds, M. C., Wang, M. C., \& Walberg, H. J. (1987). The necessary restructuring of special and regular education. Exceptional Children, 3, 391398.

Sackett, G. (1978) Observing Behavior, Vol. 2. Data collection and analysis. Baltimore, MD: University Park Press.

Saudargas, R., \& Creed, V. (1980). State event classroom observation system. Unpublished observation manual. Knoxville:University of Tennessee.

Short, E. J., \& Ryan, E. B. (1984). Metacognitive differences between skilled and less skilled readers: Remediating deficits through story grammar and attribution training. Journal of Educational Psychology, 76, 225-235.
Sindelar, P. T., Monda, L. E., \& O'Shea, L. J. (1990). The effects of repeated readings on instructional and mastery level readers. Journal of Educational Research, 83, 220-226.

Siperstein, G. N., \& Goding, M. J. (1985). Teachers' behavior toward LD and non-LD children: A strategy for change. Journal of Learning Disabilities, 18(3), 139-144.

Slate, J. R., \& Saudargas, R. A. (1986). Differences in learning disabled and average students' classroom behaviors. Learning Disability Quarterly, 9, 61-67.

Slate, J. R., \& Saudargas, R. A. (1987). Classroom behaviors of LD, seriously emotionally disturbed, and average children: A sequential analysis. Learning Disability Quarterly, 10, 125-134.

Stainback, W., \& Stainback, S. (1984). A rationale for the merger of special and regular education. Exceptional Children, 51, 102-111.

Stanley, S. O., \& Greenwood, C. R. (1981). CISSAR: Code for Instructional Structure and Student Academic Response: Observer's Manual. Kansas City: University of Kansas Juniper Gardens Children's Project, Bureau of Child Research.

Thurlow, M., Graden, J., Greener, J., \& Ysseldyke, J. (1983). LD and non-LD students' opportunities to learn. Learning Disability Quarterly, 6, 172-183.

Thurlow, M. L., Ysseldyke, J. E., Graden, J., \& Algozzine, B. (1984). Opportunity to learn for LD students receiving different levels of special education services. Learning Disability Quarterly, 7, 55-67.

Torgeson, J. K. (1977). The role of nonspecific factors in the task performance of learning disabled children: A theoretical assessment. Journal of Learning Disabilities, 10, 27-34.

Torgeson, J.K. (1982). The learning-disabled child as an inactive learner: Educational implications. Topics in Learning and Learning Disabilities, 2, 45-52.

Will, M. C. (1986). Educating children with learning problems: A shared responsibility. Exceptional Children, 52, 411-415.

Ysseldyke, J. E., Christenson, S. L., Thurlow, M. L., \& Bakewell, D. (1987). Instructional tasks used by mentally retarded, learning disabled, emotionally disturbed and nonhandicapped elementary students (Research Report No. 2). Minneapolis: Instructional Alternatives Project, University of Minnesota.

Ysseldyke, J. E., Thurlow, M. L., Christenson, L. L., \& Weiss, J. (1987). Time allocated to instruction of mentally retarded, learning disabled, emotionally disturbed, and nonhandicapped elementary students (Report No. 1). Minneapolis: University of Minnesota.

Ysseldyke, J. E., Thurlow, M. L., Mecklenburg, C., Graden, J., \& Algozzine, B. (1984). Changes in academic engaged time as a function of assessment and special education intervention. Special Services in The Schools, I(2), 31-43.

Zigmond, N., Kerr, M. M., \& Schaeffer, A. (1988). Behavior patterns of learning-disabled and non-learn- 
ing-disabled adolescents in high school academic classes. Remedial and Special Education, 9(2), 6-11.

\section{ABOUT THE AUTHORS}

JANIS A. BULGREN is an Assistant Scientist and courtesy Assistant Professor in the Department of Special Education at the University of Kansas Institute for Research in Learning Disabilities, Lawrence. JUDITH J. CARTA (CEC \#436) is an Associate Scientist at the Juniper Gardens Children's Project, Kansas City, Schiefelbusch Institute for Life Span Studies, at the University of Kansas, Lawrence.

This project was supported by a grant from the U. S. Department of Education (G008630071).

The authors wish to thank Carmen Arreaga-Mayer, Charles Greenwood, and Mary Todd, Juniper Gardens Children's Project, at the University of Kansas, Kansas City.

Manuscript received December 1989; revision accepted October 1991.
A National Conferenge Transition Into Tomorrow's Workplaces Educating and Employing Indivlduals with Disabilities

March 11-13, 1993

Minneapolis, Minnesota

NEW MINNEAPOLIS HILTON HOTEL IN THE MEART OF THE DOWNTOWN SKYWAY SYSTEM For:

- Educators in Special and Vocational Education

- Employers - Parents • Students Conference Cost:

Professionals - $\$ 125$, Parents/Consumers - $\$ 50$ Hotel Costs:

$\$ 85$ (single/double)

Practical ideas for educating individuals with disabilities for the world of work. Special emphasis on physically handicapped and other health impaired, learning disabled, emotionally/behaviorally disordered, hearing impaired, and visually impaired individuals.

$$
\text { Sponsored by }
$$

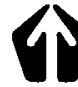

Intermediate District 287

Hennepin Technical College 820 North Xenium Lane Minneapolis, MN 55441

For registration packet contact: Jane Kist Toll Free Number: 1-800-345-4655

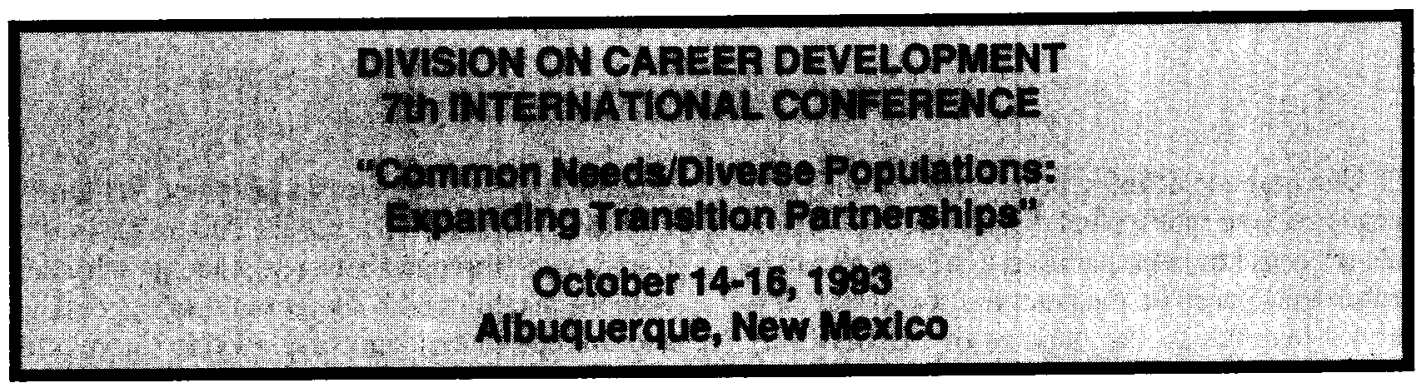

Seeking Presentations On:

Multicultural Perspectives

Supported Employment

Transition Planning

Rural/Urban Issues

Self-Advocacy

Voc Ed/Sp Ed Collaboration
Independent Living

Family Partnerships

Post-Secondary Education

Policy/Legal Issues

At-Risk/Alternative

Technology Applications

\section{Co-Sponsored by the New Mexico Department of Education}

For Applications/information:

Juidy Schatzman, Abuquerque Public Schools

P. O. Box 25704 Albuquerque, New Mexico 87125

(505-842-3741) 